\title{
Analysis of Bilateral Input-Output Trading between Vietnam and China*
}

\author{
Quang Thai NGUYEN ${ }^{1}$, Bui TRINH ${ }^{2}$, Thang Loi NGO ${ }^{3}$, Manh Dung TRAN ${ }^{4}$ \\ Received: April 09, 2020 Revised: April 17, 2020 Accepted: May 01, 2020
}

\begin{abstract}
This study attempts to analyze trade flows between Vietnam and China in order to understand the mutual influence of bilateral trade relations. China is a country with the world's leading economic potential. China and Vietnam are neighboring countries sharing a border of $1,281 \mathrm{~km}$. Trade relations between the two countries are a necessity and, with a right policy, are beneficial to both. Vietnam has a trade deficit with China. This situation is exacerbated by the continuing rise in the gap. Vietnam trade deficit from China was USD12.5 billion in 2010, increasing to USD24 billion in 2018. Data are extracted from the 2015 national input-output tables of Vietnam and China as well as Vietnam Household Living Standard Survey statistics. The research identified 36 sectors of bilateral input-output trade between Vietnam and China. A bilateral output-input model is applied to analyze how final demand and use of input in the production of this country induces output and value added of the other country. The results show that China benefits more from Vietnam's production and consumption than Vietnam does. Vietnam's inter-sector structure does not stimulate domestic production due to the absence of supporting products as inputs in the production process.
\end{abstract}

Keywords : Bilateral Trade, China, Input and Output Model, Vietnam

JEL Classification Code: P33, P45, R15

\section{Introduction}

China is a country with the world's leading economic potential. China and Vietnam are two neighboring countries sharing a border of $1,281 \mathrm{~km}$. Trade relations between the two countries are a necessity, and if there is a right policy, it is beneficial for the development of both Vietnam and

*We would like to thank Mr. Bui Can, Ms. Vy Phan for their supports on this res* Acknowledgement: We would like to thank Mr. Bui Can, Ms. Vy Phan for their supports on this research.

${ }^{1}$ First Author. Professor, Vietnam Development Research Institute. Email: thai.nguyenquang@gmail.com

${ }^{2}$ PhD Researcher, Vietnam Development Research Institute. Email: buitrinhcan@gmail.com

3Professor, National Economics University, Vietnam. Email: loint@ neu.edu.vn

${ }^{4}$ Corresponding Author. Associate Professor, The National Economics University, Vietnam [Portal Address: 207 Giai Phong Road, Dong Tam Ward, Hai Ba Trung District, Hanoi, 116000, Vietnam] Email: manhdung@ktpt.edu.vn

(c) Copyright: The Author(s)

This is an Open Access article distributed under the terms of the Creative Commons Attribution Non-Commercial License (http://Creativecommons.org/licenses/by-nc/4.0/) which permits unrestricted noncommercial use, distribution, and reproduction in any medium, provided the original work is properly cited.
China in their trade relationship. Vietnam has always a trade balance deficit with China. This situation is exacerbated by the fact that Vietnam trade deficit with China increases from USD12.5 billion in 2010 to USD24 billion in 2018, and during the first nine months of 2019, the trade deficit was already USD24 billion (Figure 1).

This study attempts to analyze trade flows between Vietnam and China in order to examine the mutual influence in bilateral trade relations. The study uses a bilateral outputinput model to analyze how final demand and use of input in the production of this country induce output and value added of other country.

National input-output table in the most basic way of understanding output and value added, sees imports induced by inter-industry relations and final demand. The intercountry input-output system aims to measure the fluctuation in production and final demand of one country in respect of production and income of another country. Production effects on a State include:

Multiplier effects; it includes direct and indirect effects on output induced by domestic final demand.

International feedback effects: there are output requirements of country $\mathrm{A}$ induced by production of country $\mathrm{B}$ that used products of country A for intermediate input. 


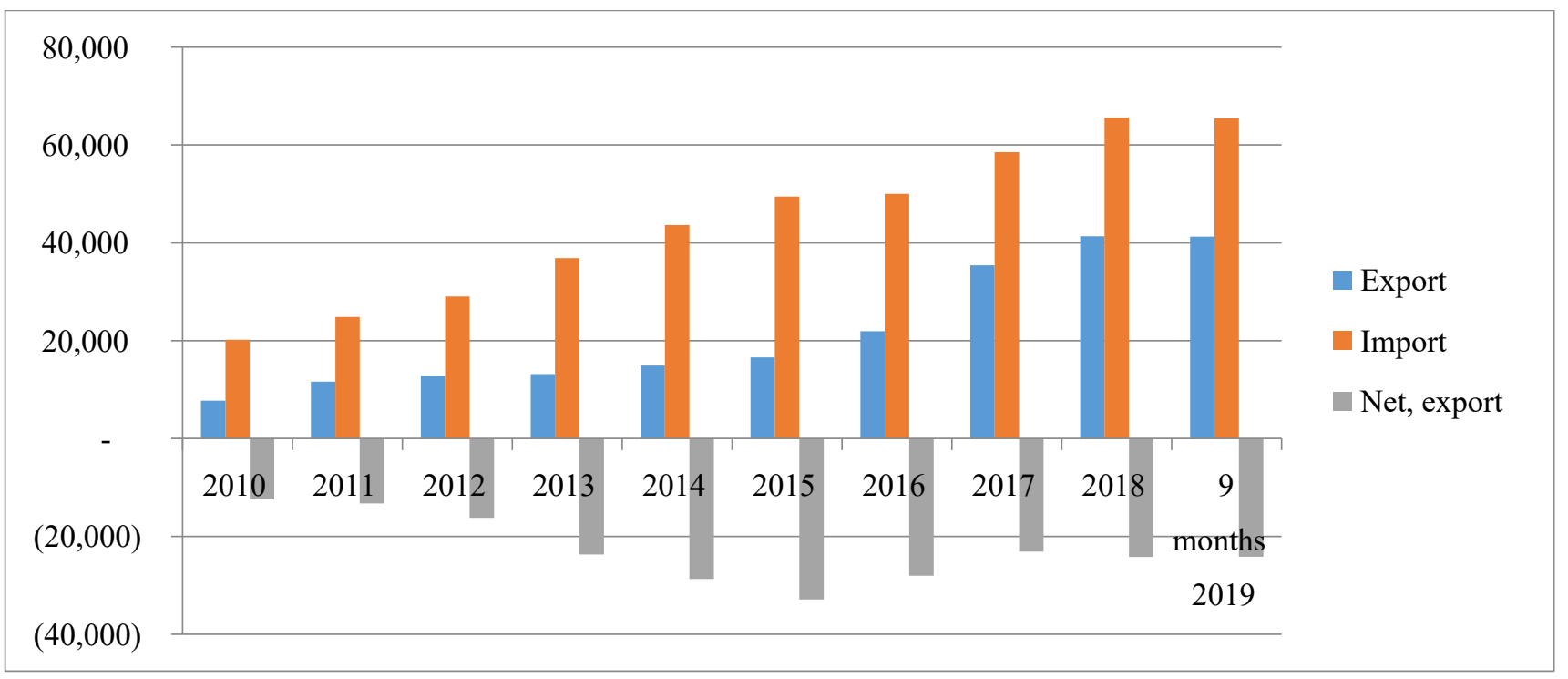

Source: General Statistics Office (2019)
Figure 1: Export, import and net export of Vietnam from China (billion)

Spillover effects: the import demand of country A for the products of country B. This means domestic final demand is not only induced by it own outputs, but also induced by outputs of other countries.

In general, the output and value added of one nation can be created by the final use of another country. According to Noguera (2012), the value added purchased abroad was called VAX-C. Los \& Timmer (2018) proposed measuring the added value of country A when exporting to country B for production needs called VAX-P. Gross value added in bilateral trade flows (VAX-D) was mentioned by Los et al. (2016). Other studies were related to commercial flows such as Bems et al. (2011, 2013), Bui et al. (2008), Nguyen \& Lam (2017), Muchdie \& Sugema (2017), Oosterhaven \& Stelder (2007), Muchdie \& Narmaditya (2019), He \& Wang (2019), and Tran \& Nguyen (2018).

This study examines the output and the value added of a nation created by the ultimate domestic final demand and the production requirements of another country. This spread is understood when country A uses country B products for final demand that will eventually lead to country B's production stimulation. Due to national manufacturing process, country B uses country A's products as an intermediary cost, resulting in a backward stimulus to country A's output; country B uses country A's products for final needs and as soon as country B uses its own domestic production, it will lead to a change in country B's own production. When country B uses products of country A as input costs, it will spread to country A's output (see Figure 2).

The inter-country input-output table has the same structure as the inter-regional input-output table, while the inter-regional input-output table in one country describes intra-trade flows with other regions, the inter-country inputoutput table describes foreign trade flows between one country and another. The Leontief input-output system has been developed into an inter-regional (or inter-country) input-output model by Isard (1951); the idea of interregional input-output model was developed by Richardson (1972) and Miyazawa (1976). The inter-regional inputoutput model not only describes inter-sectorial relations, but also describes inter-regional relations through trade flows between one region and another (outside). The inter-regional model was perfected by Chenery-Moses (also known as the Chenery-Moses model). Recent contributions come from Miller-Blair (1985), Hewings \& Jensen (1986), Ihara (1999), and Bui (2017).

A study comparing the economic structure between Vietnam and China was also investigated by Bui and Pham (2014). However, this study only compares the economic structure between the two countries and does not expand the analysis of reciprocal effects of trade flows between the two countries. Previously, the inter-national input-output model of Vietnam and Thailand was also studied by Kwangmoon et al. (2011) and presented at a workshop of the International Input-Output Association (IIOA).

\section{Data Collection}

The national input-output tables of Vietnam and China in 2015 were used for compiling data within bilateral inputoutput framework. The 2015 national input-output table of China was issued by the National Bureau of Statistics of 


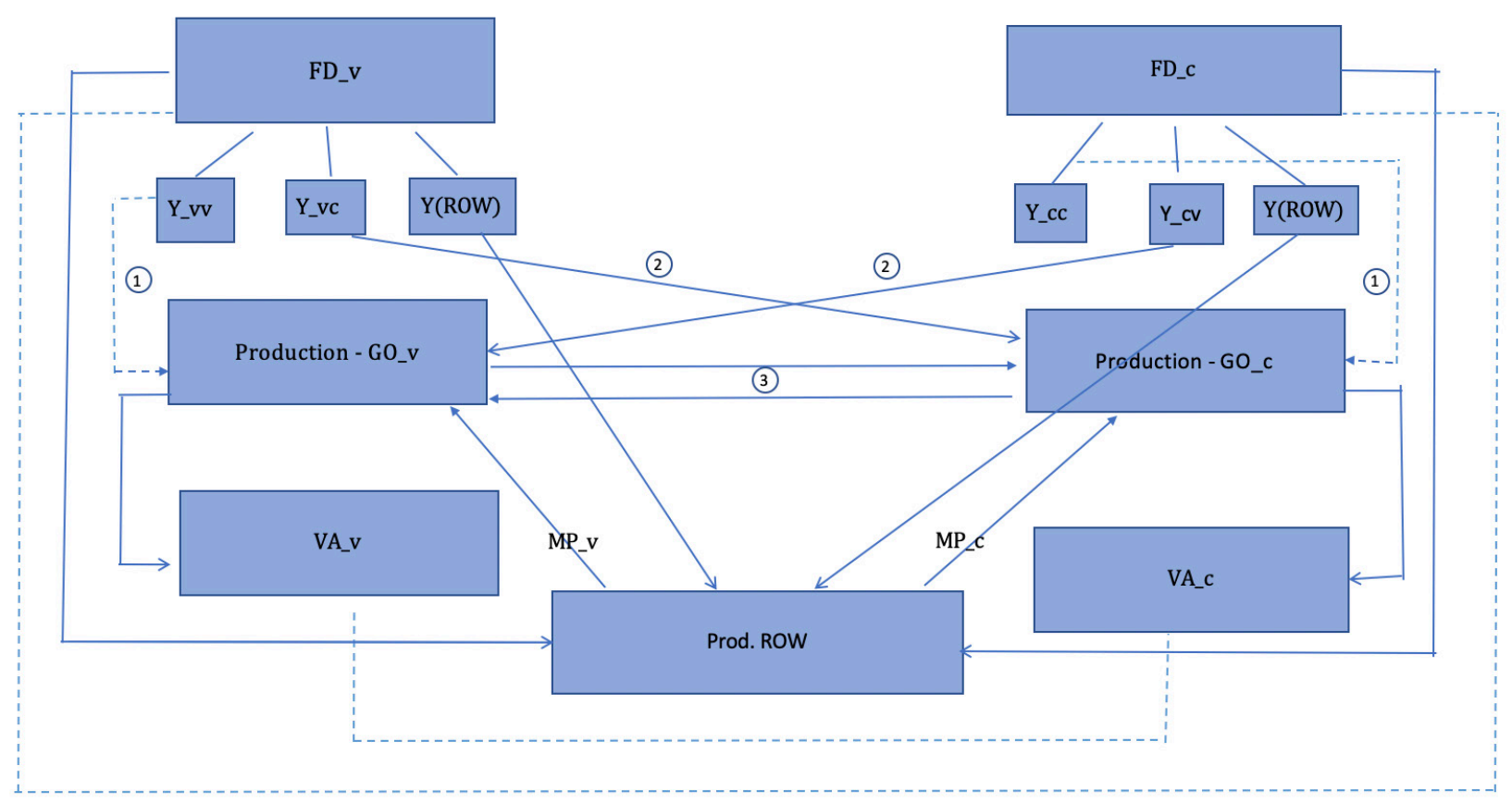

Note: (1) Multiplier effects; (2) Spillover effects; (3) inter_national feedback effects

Figure 2: Relationship in bilateral input - output model

China. The last input-output table of Vietnam dates from 2012. The Vietnam development research institute compiled the country's national input-output table in 2015. The approach for compiling these data are based on Vietnam's national input-output of 2012 and vectors of intermediate input and gross output from firm survey and data from Vietnam Household Living Standard Survey (VHLSS) as well as data on gross capital formation, export and import of goods and services collected from Vietnam's General Statistics Office. The RAS method was, then, employed for balancing gross input and gross output of input-output table (Lahr and de Mesnard, 2004; Miller \& Blair, 2009; Bui \& Nguyen, 2013, Bui et al., 2018).

There are 36 sectors of bilateral input-output between Vietnam and China, presented in Appendix 1. The general framework of bilateral input-output system between Vietnam and China is described in Table 1:

The unit of bilateral input-output table between Vietnam and China is in USD million. The exchange rate was the 2015 average rate: $1 \mathrm{USD}=6.3597$ YUAN; $1 \mathrm{USD}=21,673$ VND.

\section{Research Methodology}

The basic relationship of Leontief is as follows:

$$
\mathrm{X}=(\mathrm{I}-\mathrm{A})^{-1} \cdot \mathrm{Y}
$$

Where: $\mathrm{X}$ is a vector of output, $\mathrm{I}$ is an identity matrix, $\mathrm{A}$ is a direct input coefficient matrix, $\mathrm{Y}$ is a matrix of final demand.

In bilateral input-output system, the matrix A includes sub-matrices as follows:

$$
\mathrm{A}=\left[\begin{array}{ll}
A_{V V} & A_{V C} \\
A_{C V} & A_{C C}
\end{array}\right]
$$

Where:

Avv is a coefficient matrix of intermediate input of Vietnam using Vietnam's products;

Avc is a coefficient matrix of intermediate input of China using Vietnam's products;

Acv is a coefficient matrix of intermediate input of Vietnam using China's products;

Acc is a coefficient matrix of intermediate input of China using China's products;

Gross output vector $(\mathrm{X})$ was divided gross output vector of Vietnam (Xv) and China (Xc)

$$
\mathrm{X}=\left[\begin{array}{c}
X_{V} \\
X_{C}
\end{array}\right]
$$

Final demand matrix is expressed:

$$
\mathrm{Y}=\left[\begin{array}{ll}
Y_{V V} & Y_{V C} \\
Y_{C V} & Y_{C C}
\end{array}\right]
$$


Table 1: The bilateral input - output system between Vietnam and China

\begin{tabular}{|l|c|c|c|c|c|c|}
\hline & & \multicolumn{2}{|c|}{ Intermediate input } & \multicolumn{2}{c|}{ Final demand } & Gross output \\
\hline & & Vietnam & China & Vietnam & China & \\
\hline \multirow{2}{*}{ Intermediate consumption } & Vietnam & $\mathrm{Xvv}$ & $\mathrm{Xvc}$ & $\mathrm{Yvv}$ & $\mathrm{Yvc}$ & $\mathrm{Xv}$ \\
\cline { 2 - 7 } & $\mathrm{China}$ & $\mathrm{Xcv}$ & $\mathrm{Xcc}$ & $\mathrm{Ycv}$ & $\mathrm{Ycc}$ & $\mathrm{Xc}$ \\
\hline Rest of the world (ROW) & & $\mathrm{MPv}$ & $\mathrm{MPc}$ & $\mathrm{MYv}$ & $\mathrm{MYc}$ & \\
\hline Value added & & $\mathrm{VAv}$ & $\mathrm{VA}_{\mathrm{c}}$ & & & \\
\hline Gross input & & $\mathrm{Xv}$ & $\mathrm{Xc}$ & & & \\
\hline
\end{tabular}

Where:

Xvv: Intermediate input of Vietnam used Vietnam's products;

Xvc: Intermediate input of China used Vietnam's products;

Xcv: Intermediate input of Vietnam used China's products;

Xcc: Intermediate input of China used China's products;

Yvv: Final demand of Vietnam used themselves products;

Yvc: Final demand of China used Vietnam's products;

Ycv: Products of China for final demand of Vietnam;

Ycc: Final demand of Vietnam used themselves' products;

MPv: Import from rest of the world (ROW) for intermediate input of Vietnam;

MPc: Import from rest of the world (ROW) for intermediate input of China;

MYv: Import from rest of the world (ROW) for final demand of Vietnam;

MYc: Import from rest of the world (ROW) for final demand of China;

VAv, VAc, Xv và Xc are vectors of value added and gross output of Vietnam and China corresponding.

Where:

Yvv being the last demand matrix of Vietnam using domestic products;

Yvc is the last demand matrix of China using Vietnamese products;

Ycv is the last demand matrix of Vietnam using Chinese products;

Ycc is China's last demand matrix using domestic products.

Put:

$\mathrm{B}=(\mathrm{I}-\mathrm{A})-1=\left[\begin{array}{ll}B_{v v} & B_{v c} \\ B_{c v} & B_{c c}\end{array}\right]$

Leontief basic relationship has the form:

$$
\mathrm{X}=\mathrm{B} . \mathrm{Y}
$$

Bij is sub-matrix of Leontief inverse matrix that shows one unit of change in the production of a certain sector can lead to a combination of both direct and indirect changes in other industrial sectors.

$$
\mathrm{X}=\left[\begin{array}{c}
X_{V} \\
X_{C}
\end{array}\right]=\left[\begin{array}{cc}
B_{v v} \cdot Y_{v v}+B_{v c} \cdot Y_{c v} & B_{v c} \cdot Y_{c c}+B_{v v} \cdot Y_{v c} \\
B_{c v} \cdot Y_{v v}+B_{c c} \cdot Y v c & B_{c c} Y_{c c}+B_{c v} \cdot Y_{v c}
\end{array}\right]
$$

From the relationship (7), it can be seen that the production value of Vietnam and China is spread by:

$$
\begin{aligned}
& X v=\text { Bvv.Yvv }+ \text { Bvc.Ycv }+ \text { BvcYcc }+ \text { BvvYvc } \\
& X c=\text { Bcv.Yvv }+ \text { Bcc.Ycv }+ \text { Bcc.Ycc }+ \text { Bcv.Yvc }
\end{aligned}
$$

The above relation shows that the production value of a country is created by (i) the final domestic demand; (ii) production needs of another country. This spread is understood when country A consumes country B's products for a demand that will eventually lead to country B's production stimulation. In the national production process, country B using national products creates a mediated stimulation leading to reversing the nation's output A; (iii) country B uses country A products for its final needs; and (iv) as soon as country B uses its own domestic production, it will lead to a change in country B's own production. Where country B uses products of country A as input costs, it will spread to country A's output.

The matrix offspring should be interpreted as a measure of the value of production caused by the influence of one unit of final demand and production of water for other countries.

\section{Multiplier effects:}

Measures the change in production caused by a unit of final domestic demand:

$$
\text { (I-Avv)-1, (I-Acc)-1. }
$$


International Feedback effects:

Measure change in production from one country to another country:

Bvv - (I - Avv)-1 or Bcc - (I - Acc)-1

\section{Spillover effects:}

Measure the demand for a country's output when there is a change in the final demand of another country: Bcv and Bvc.

The added value of each country is measured:

$(\mathrm{VR}, \mathrm{VS})=(\mathrm{vr}, \mathrm{vs}) \cdot \mathrm{X}=(\mathrm{vr}, \mathrm{vs})$.

$\left[\begin{array}{ll}X_{v v} & X_{v c} \\ X_{c v} & X_{c c}\end{array}\right]$

With:

$\mathrm{Xvv}=\mathrm{Bvv.Yvv}+\mathrm{Bvc.Ycv}$

$\mathrm{Xvc}=\mathrm{BvcYcc}+\mathrm{BvvYvc}$

$\mathrm{Xvv}+\mathrm{Xvc}=\mathrm{Xv}$

$\mathrm{Xcv}=\mathrm{Bcv} . \mathrm{Yvv}+\mathrm{Bcc} . \mathrm{Ycv}$

$\mathrm{Xcc}=$ Bcc.Ycc + Bcv.Yvc

$\mathrm{Xc}=\mathrm{Xcv}+\mathrm{Xcc}$

At that time the added value of each nation was measured:

$\mathrm{Vv}=\mathrm{Vv} \cdot \mathrm{Xvv}+\mathrm{Vv} \cdot \mathrm{Xvc}$

$\mathrm{Vc}=\mathrm{Vc} . \mathrm{Xcc}+\mathrm{Vc} . \mathrm{XcV}$
Relations (14) and (15) allow analysis of bilateral trade flows spread to the added value of each country.

\section{Results and Discussion}

Comparison of economic indicators between Vietnam and China on board I/O 2015 of two countries (Table 2) showed that when China produces USD1 million in output, it generates USD32,000 in value added, whereas when Vietnam produced USD1 million in output, it only generates USD29,000 in value added. This ratio shows Vietnam's production in China is not effective or is an economy deeply outsourcing China.

Rate input products are imported intermediate costs of Vietnam that are far greater than the proportion of China (0.29 versus 0.08$)$. It shows that China produces a lot of supporting products that participates in intermediate costs in the production process, while Vietnam, in addition to input products, produces services, electricity and water that participate to intermediate costs. They are still very few supporting products involved in intermediate costs in the manufacturing process. This shows that the spread from the final demand to the supply side of Vietnam is lower than the spread to imports.

Table 2 also shows that the trade relations between the two countries in production are also very clear and quite large. In the intermediate costs of Vietnam, $8 \%$ of inputs are imported from China, while in the intermediate cost of China only $0.1 \%$ uses input products imported from Vietnam. This partly shows that the relative importance of imported products from China to Vietnamese production is much larger than the opposite. This dependence is worth paying attention.

Table 2: Comparison through some general indicators (times)

\begin{tabular}{|l|c|c|}
\hline \multicolumn{1}{|c|}{ Items } & Vietnam & China \\
\hline Intermediary costs/production value & 0.710 & 0.673 \\
\hline Value added/production value & 0.290 & 0.327 \\
\hline Import ratio in intermediate costs & 0.289 & 0.076 \\
\hline The rate of use of each other's products in intermediate costs & 0.084 & 0.00 \\
\hline Elasticity's of labor & 0.77 & 0.69 \\
\hline Elasticity's of capital & 0.23 & 0.31 \\
\hline Percentage of final consumption by households/GVA & 0.560 & 0.360 \\
\hline Final consumption of Government/GVA & 0.060 & 0.140 \\
\hline Final consumption/GVA & 0.620 & 0.500 \\
\hline Investment/GVA & 0.220 & 0.440 \\
\hline Net export/GVA & 0.010 & 0.020 \\
\hline
\end{tabular}


The coefficient of elasticity between labor and capital of two countries through inter-sectorial balance sheets showed that Vietnam needs a higher amount of capital than China to create new growth, But the paradox is that the ratio of investment to gross value added (GVA) of Vietnam is much lower than China (22\% compared to $44 \%)$, however, the growth is still high, not much less than China's average growth period 2010-2015. Vietnam's average growth rate is about $6.1 \%$ while the average growth of China during this period is estimated at 7\%. This can only explain Vietnam's total factor productivity (TFP) is higher than China. Does this seem a paradox? So, which factors affect total factor productivity (TFP)? Does this suggest that Vietnam's growth is based heavily on the FDI sector?

The factor of the final demand shows that the final consumption of households in Vietnam accounted for a proportion of gross value added (GVA) higher than that of China by 20 percentage points (56\% compared to $36 \%$ ); Government's final consumption expenditure of China is higher than Vietnam by eight percentage points $(14 \%$ and $6 \%$ ). However, China's final consumption in gross added value (GVA) is still quite low compared to Vietnam (50\% compared to $62 \%$ ), while the share of net exports in Vietnam's GVA is even higher than China. Thus, in order to achieve China's growth based largely on investment, China's investment in GVA is very high at around $44 \%$ of GVA, while Vietnam's ratio is only $22 \%$ of GVA. This situation, if taking place for a long time, can lead to a vulnerable economy if the revenue from ownership is in trouble, and savings are always smaller than investment.

The calculation of scenarios when there is trade vulnerability between the two countries (see Table 3) shows that Vietnam is much more affected than China. In Table 3, the assumptions are made as regards how the sudden reduction of trade with China under the current conditions will affect economic growth in the worst case, GVA/GDP of Vietnam may decrease by $5.9 \%$.

This shows that Vietnam has deepened its dependence on trade relations with China for many years. Up to this point, the idea of "escaping from China" seems to be unrealistic. Thus, the trade deficit between Vietnam and China is basically due to the fact that Vietnam has hardly changed in many years; production has always depended on imports as input costs, inputs are products, and Vietnam is the basis for electricity, water, packaging and service costs only.

In general, the influence from the final demand of Chinese's gross output is higher than Vietnam. Especially, the final demand of Vietnam-induced output of China is higher in final demand than China-induces production of Vietnam. An increase of USD1 million in Vietnam's final demand generates USD318,000 of Chinese output, while an increase of USD1 million in China's final demand generates only USD3,000 worth of Vietnamese production (see Table 4).

Table 5 shows that the value added of each country is induced by the final demand and production other countries. Specifically as:

(i) China's final demand induced China's value added $48 \%$ higher than Vietnam's final demand to Vietnam's value added $48 \%$;

(ii) Vietnam's production induces China's value added 115 times higher than China's production induces Vietnam's value added.

The economic structure of Vietnam is a problem worth thinking about as the country's GDP growth is a virtual achievement that is very misleading. The study shows that GDP growth only benefits other countries, not only with

Table 3: Trade effects on GDP of Vietnam and China

\begin{tabular}{|l|c|c|}
\hline \multicolumn{1}{|c|}{ Items } & GDP Vietnam & GDP China \\
\hline Imports for manufacturing from China decreased by 10\% & -0.59 & -0.006 \\
\hline Imports for manufacturing from China decreased by 20\% & -1.19 & -0.012 \\
\hline Imports for manufacturing from China decreased by 50\% & -2.97 & -0.029 \\
\hline Cut off trade relations & -5.94 & -0.058 \\
\hline
\end{tabular}

Table 4: Dividing effects from final demand on output of two countries (times)

\begin{tabular}{|l|c|c|}
\hline & Vietnam & China \\
\hline Output requirement - (Backward linkage) & 2.337 & 2.651 \\
\hline In which: & & \\
\hline + Multiplier effects & 2.019 & 2.648 \\
\hline + International feedback effects & 0.0004 & 0.0005 \\
\hline + Spillover effects & 0.318 & 0.003 \\
\hline
\end{tabular}


Table 5: The value added of each country induced by the final demand and production other countries (times)

\begin{tabular}{|l|c|c|}
\hline & \multicolumn{2}{|c|}{ Value added } \\
\hline & Vietnam & China \\
\hline Multiplier effects on value added & 0.585 & 0.865 \\
\hline Inter - national feedback effects on value added & 0.001 & 0.104 \\
\hline Total value added & 0.586 & 0.969 \\
\hline
\end{tabular}

Source: Authors calculated from bilateral input - output table, 2015

Table 6: Demand factors finally spread to production value (\%)

\begin{tabular}{|l|c|c|c|c|c|c|c|c|}
\hline & \multicolumn{4}{|c|}{ Vietnam } & \multicolumn{4}{c|}{ China } \\
\cline { 2 - 9 } & $\begin{array}{c}\text { Final } \\
\text { consumption }\end{array}$ & $\begin{array}{c}\text { Gross } \\
\text { capital } \\
\text { formation }\end{array}$ & Export & $\begin{array}{c}\text { Average } \\
\text { of final } \\
\text { demand }\end{array}$ & $\begin{array}{c}\text { Final } \\
\text { consumption }\end{array}$ & $\begin{array}{c}\text { Gross } \\
\text { capital } \\
\text { formation }\end{array}$ & Export & $\begin{array}{c}\text { Average } \\
\text { of final } \\
\text { demand }\end{array}$ \\
\hline Vietnam & 84 & 81 & 86 & 85 & 0.2 & 0.11 & 0.06 & 0.1 \\
\hline China & 16 & 19 & 14 & 15 & 99.8 & 99.89 & 99.94 & 99.9 \\
\hline Gross output & 100 & 100 & 100 & 100 & 100 & 100 & 100 & 100 \\
\hline
\end{tabular}

Chinese partners, but also with almost all countries having trade relations with Vietnam because Vietnam does not have enough supporting products, Even Vietnamese production uses very little of the input which is domestically produced except electricity, water and service costs.

Appendix 2 shows the breakdown of the total effect of how much the increase in the final demand unit of a region spreads to the input of each country. How much the final demand of country A stimulates internal output of that country (Multiplier effects)? How much is due to country B's production stimulating the output of country A (International feedback effects)? And how much of the country A's final demand stimulated the national output of county B? In this section, there are 36 sectors, which show the influence on output of industries due to the impact of the final demand.

Vietnam's domestic sectors stimulated (benefiting) from Chinese manufacturing include: Textile (sector 4), Textile clothing, shoes and hats, leather and its products (sector 5), Printing paper and paper products (Sector 7), Transport equipment (13), Communications equipment, computers and other electronic devices (14), Specialized machinery and equipment (18), Other manufactured products (19), Information transfer, software and information technology services (27). The final demand for some Vietnamese products spread very strongly to Chinese production such as Textile (sector 4), Textile clothing, shoes and hats, leather and its products (sector 5), Printing of paper and paper products (7), Petroleum, coking products and products of processing nuclear fuel (9), Metal products (12), Transport equipment (13), Equipment communication equipment, computers and other electronic devices (14), Repair of metal products, machinery and equipment (15), Instrumentation (16), Specialized machinery and equipment (17), Other manufactured products (18), Construction (23), Transport, warehousing and postal services (25). Although some sectors entertain mutual stimulation, the weight of the spillover from Chinese manufacturing to Vietnam's output is too low compared to the needs of Vietnam finally spreading to the output of China. Strangely, the final demand of waste materials spread so highly to the output of this product group, what does this mean? Is Vietnam stimulating import of waste from partner countries? Many people think that Vietnam is a dump area for another country.

Vietnam's production stimulates China's output much more than Chinese production stimulates Vietnam's output (0.0004 compared to $0.001-88 \%$ ) (Appendix 3). In addition, Vietnam's final demand induces China's output in a bigger way than China's final demand induces Vietnam's output. Vietnam's final aggregate demand increased by USD1 million, stimulating China's output to increase by USD 323,000 , while China's final aggregate demand increased by USD million, stimulating Vietnam's production of only about USD3,000. In the inter-regional or inter-country input-output model, a country's products are divided for domestic final needs (final consumption, asset accumulation and exports to countries other than foreign countries partners) and the final demand of the partner country.

Table 6 illustrates that $85 \%$ of Vietnam's gross output was generated by domestic final demand and $15 \%$ was generated by the partner country's final demand, meanwhile $99 \%$ of 
Table 7: Production value is spread by the final demand and its components

\begin{tabular}{|l|c|c|c|c|}
\hline The production value is spread by & Vietnam (\%) & China (\%) & $\begin{array}{c}\text { Vietnam } \\
\text { (mill USD) }\end{array}$ & $\begin{array}{c}\text { China (million } \\
\text { USD) }\end{array}$ \\
\hline Total domestic final demand & $\mathbf{1 0 0 . 0}$ & $\mathbf{1 0 0 . 0}$ & 667,204 & $42,923,927$ \\
\hline Vietnam & 92.0 & 0.3 & 614,152 & 111,329 \\
\hline China & 8.0 & 99.7 & 53,052 & $42,812,598$ \\
\hline Final consumption & $\mathbf{1 0 0 . 0}$ & $\mathbf{1 0 0 . 0}$ & 272,991 & $14,212,621$ \\
\hline Vietnam & 89.5 & 0.3 & 244,380 & 46,749 \\
\hline China & 10.5 & 99.7 & 28,611 & $14,165,872$ \\
\hline Accumulation & $\mathbf{1 0 0 . 0}$ & $\mathbf{1 0 0 . 0}$ & 99,470 & $16,156,925$ \\
\hline Vietnam & 82.5 & 0.1 & 82,041 & 19,323 \\
\hline China & 17.5 & 99.9 & 17,429 & $16,137,602$ \\
\hline Export & $\mathbf{1 0 0 . 0}$ & $\mathbf{1 0 0 . 0}$ & 294,743 & $12,554,380$ \\
\hline Vietnam & 97.6 & 0.4 & 287,731 & 45,257 \\
\hline China & 2.4 & 99.6 & 7,011 & $12,509,124$ \\
\hline
\end{tabular}

Chinese output was created through domestic final demand of only $0.1 \%$ due to Vietnam's final demand. This suggests that the perception that Chinese tourists do not spend much in Vietnam is not objective.

However, due to the size of the Chinese economy, even $0.3 \%$ of the total production value that is spread by the final demand of Vietnam is about USD111 billion, while Vietnam's production value is spread by China's final demand of $8 \%$ of the total production value, but only about USD53 billion of the USD 667 billion output of Vietnam is the elements of final demand (see Table 7).

The value added of Vietnam and China generated by the factors of final demand and production of other countries are very different (Appendix 4). The total value of China's value added generated by an additional unit of final demand and Vietnam's production is about $54 \%$ higher than what Vietnam received from these factors $(0.943$ versus 0.612$)$. It is noteworthy that Vietnam's production spread to the value added of China is nearly 100 times higher than the production China induces In Vietnam's value added. Especially, a manufacturing group such as Textile (Sector 4), Textile apparel, shoes and hats, leather and articles thereof (Sector 5), Petroleum, coke products and products of processing nuclear fuel (Sector 8), Metal products (Sector 11), Electrical machinery (Sector 12), Transport equipment (Sector 13), Communications equipment, computers and other electronic devices (Sector 14), Machinery and specialized equipment (Sector 17), Other manufacturing products (Sector 18) and information technology transfer, software and IT services (Sector 27). This fact shows that Vietnam's production is highly priced and the input is mostly made in China. This can only be blamed on more than 20 years of industrialization, but almost no production of auxiliary products. This also partly proves that the more labor is involved in the manufacturing and manufacturing group, the more the trade deficit between Vietnam and China widens.

In short, trade relation is not only a question of trade deficit, but is also closely related to the structure of the economy. The inter-country input-output table shows that China benefits more from Vietnam's production and consumption than vice versa. Vietnam's inter-sector structure does not stimulate domestic production due to the absence of supporting products as inputs in the production process. With such a structure, if Vietnam were not dependent on Chinese inputs, it would be dependent on other countries. Thus, looking only at the GDP growth figures and not at the structure of the economy can lead to a turbulent future.

\section{References}

Bems, R., Johnson, R.C., \& Yi, K.M. (2011). Vertical Linkages and the Collapse of Global Trade. American Economic Review, 101(3), 308- 12.

Bems, R., Johnson, R.C., \& Yi, K.M. (2013). The Great Trade Collapse. Annual Review of Economics, 5(1), 375-400.

Bui, T. (2017). Interregional Structure Analysis Based On Three Regions of Vietnam. Advances in Social Sciences Research Journal, 4(7), No.7, 38-44.

Bui, T. \& Pham, L.H. (2014). Some Findings of Vietnam's Economic Situation in the Relationship with China. American Journal of Economics, 4(5), 213-217.

Bui, T., Pham, L.H., \& Bui, C.G. (2008). Import multiplier in inputoutput analysis. Depocen Working Paper Series No. 2008/23. 
Bui, T., \& Nguyen, V.P. (2013). A Short Note on RAS Method. Advances in Management \& Applied Economics, 3(4), 133137.

Bui, T., Nguyen, V.P., \& Bui, Q. (2018). The RAS Method with Random Fixed Points. Journal of Economics and Business, 1(4), 640-646.

GSO (2019). Statistic Yearbook. Statistics Publishing House, Vietnam.

He, Y., \& Wang, J. (2019). A Panel Analysis on the Cross Border E-commerce Trade: Evidence from ASEAN Countries. Journal of Asian Finance, Economics and Business, 6(2), 95-104. https://doi.org/10.13106/jafeb.2019.vol6.no2.95

Hewings, G.J.D, \& Jensen, R.C. (1986). Regional interregional and multiregional input-output analysis. In Handbook of regional and urban economics. Chapter 8 in Handbook of Regional and Urban Economics, Vol. 1. Elsevier Science Publishers BV.

Ihara, T. (1999). Diagnosis and Therapy of Interregional feedback effect. Heidelberg, Germany: Springer Verlag.

Isard, W. (1951). Interregional and regional input-output analysis: A model of a space-economy. Review of Economics and Statistics, 33(4), 318-328.

Kwangmoon, K., Secretario, F., Bui, T., \& Kaneko, H. (2011). Developing a Bilateral Input-Output Table in the Case of Thailand and Vietnam: Methodology and Applications. Proceedings of $19^{\text {th }}$ International Input-Output Conference (pp.1-36). Washington DC, USA, 13-17 June, 2011.

Lahr, M.L., de Mesnard, L. (2004). Bi-proportional techniques in input-output analysis: table updating and structural analysis. Economics System Research, 16, 115-134.

Los, B., \& Timmer, M.P. (2018). Measuring bilateral exports of values added: A unified framework. Working Paper (pp. 1-29). National Bureau of Economics Research. Massachusetts Avenue Cambridge.

Los, B., M. P. Timmer and G. J. de Vries (2016). Tracing ValueAdded and Double Counting in Gross Exports: Comment. American Economic Review, 106(7), 1958-1966.
Miller, R.E., Blair, P.D. (2009). Input-Output Analysis Foundations and Extensions ( $2^{\text {nd }}$ Ed). New York: Cambridge University Press.

Miyazawa, K. (1976). Input-Output Analysis and the Structure of Income Distribution. Lecture Notes in Economics and Mathematical Systems. Berlin: Springer-Verlag.

Muchdie, M., \& Narmaditya, B.S. (2019). Are Trades Related to Technology? Evidences from the Baltic States: Estonia, Latvia and Lithuania. Journal of Asian Finance, Economics and Business, 6(2), 83-93. https://doi.org/10.13106/jafeb.2019. vol6.no2.83

Muchdie, M., \& Sugema, H. (2017). Technical and Trade Coefficients in China and in the USA Economies: Are They Different?. International Journal of Advanced Research, 5(11), 377-390.

Nguyen, T.H.T.B., \& Lam, A.H. (2017). Financial Development, International Trade, and Stock Market Integration: Evidence in Six Southeastern Asia Countries. Journal of Economics and Development, 19(3), 5-17.

Nguyen, N.T., Bui, T., \& Nguyen, V.P. (2018). Interregional InputOutput Analysis between the Mekong Delta Region (MDR) and the Rest of Vietnam (ROV). Research in Economics and Management, 3(3), 288-306.

Noguera, G. (2012). Trade Costs and Gravity for Gross and Value Added Trade. University of California at Berkeley and Columbia University, Mimeo.

Oosterhaven, J. \& Stelder, D. (2007). Regional and Interregional IO Analysis. Faculty of Economics and Business University of Groningen, the Netherlands, Retrieved from https://www.rug. $\mathrm{nl} / \mathrm{research} / \mathrm{reg} / \mathrm{research} /$ irios/download/regional-io-analysis. pdf

Richardson, H. W. (1979). Regional Economic. Urbana, MI: University of Illinois Press.

Tran, T.D., \& Nguyen, T.C.V. (2018). Impact of Globalization on Economic Growth in Vietnam: An Empirical Analysis. Journal of Economics and Development, 20(1), 32-47. 
Appendix 1: Sectors in bilateral input output table

\begin{tabular}{|c|c|}
\hline No. & Name of sectors \\
\hline 1 & Agriculture, forestry, animal husbandry and fishery products and services \\
\hline 2 & Extractive \\
\hline 3 & Food and tobacco \\
\hline 4 & Textile \\
\hline 5 & Textile clothing, shoes and hats, leather and products thereof \\
\hline 6 & Wood processing products and furniture \\
\hline 7 & Print paper and sports culture and education \\
\hline 8 & Petroleum, coking products and products processing nuclear fuel \\
\hline 9 & Chemical products \\
\hline 10 & Non-metallic mineral products \\
\hline 11 & Metal products \\
\hline 12 & Electric machinery \\
\hline 13 & Transport equipment \\
\hline 14 & Communications equipment, computers and other electronic devices \\
\hline 15 & Repairing metal products, machinery and equipment \\
\hline 16 & Instrumentation \\
\hline 17 & Machinery, specialized equipment \\
\hline 18 & Other manufactured products \\
\hline 19 & Producing and supplying electricity \\
\hline 20 & Producing and supplying gas \\
\hline 21 & Producing and supplying water \\
\hline 22 & Waste scrap \\
\hline 23 & Construction \\
\hline 24 & Wholesale and retail \\
\hline 25 & Transportation, warehousing and postal services \\
\hline 26 & Accommodation \& Dining \\
\hline 27 & Information transfer, software and information technology services \\
\hline 28 & Finance \\
\hline 29 & Real estate \\
\hline 30 & Leasing and business services \\
\hline 31 & Scientific research and technical services \\
\hline 32 & Other services \\
\hline 33 & Education \\
\hline 34 & Health and social work \\
\hline 35 & Culture, sports and entertainment \\
\hline 36 & Public administration, social security and social organization \\
\hline
\end{tabular}


Quang Thai NGUYEN, Bui TRINH, Thang Loi NGO, Manh Dung TRAN /

Journal of Asian Finance, Economics and Business Vol 7 No 6 (2020) 157 - 172

Appendix 2: Analyzing output requirement induced by a unit increase of final demand of Vietnam

\begin{tabular}{|c|c|c|c|c|c|c|c|c|c|}
\hline \multirow[b]{3}{*}{ No. } & \multirow[b]{3}{*}{ Sectors } & \multicolumn{8}{|c|}{ Vietnam } \\
\hline & & \multirow[b]{2}{*}{$\begin{array}{c}\text { Output } \\
\text { requirements }\end{array}$} & \multicolumn{3}{|c|}{ In which } & \multirow[b]{2}{*}{$\begin{array}{c}\text { Average } \\
\text { of Output } \\
\text { requirements }\end{array}$} & \multicolumn{3}{|c|}{ In Which } \\
\hline & & & $\begin{array}{c}\text { Multiplier } \\
\text { effects }\end{array}$ & $\begin{array}{c}\text { Interregional } \\
\text { feedback } \\
\text { effects }\end{array}$ & $\begin{array}{c}\text { Spillover } \\
\text { Effects }\end{array}$ & & \begin{tabular}{|c|} 
Average of \\
Multiplier \\
effects
\end{tabular} & $\begin{array}{c}\text { Average of } \\
\text { Interregional } \\
\text { feedback } \\
\text { effects }\end{array}$ & $\begin{array}{c}\text { Average } \\
\text { of } \\
\text { Spillover } \\
\text { Effects }\end{array}$ \\
\hline 1 & $\begin{array}{l}\text { Agriculture, } \\
\text { forestry, animal } \\
\text { husbandry and } \\
\text { fishery products } \\
\text { and services }\end{array}$ & 2.298 & 2.116 & 0.0002 & 0.182 & 1.0396 & 1.2460 & 0.5261 & 0.6249 \\
\hline 2 & Mining & 1.939 & 1.665 & 0.0002 & 0.273 & 0.8773 & 0.9808 & 0.5666 & 0.9398 \\
\hline 3 & $\begin{array}{l}\text { Food and } \\
\text { tobacco }\end{array}$ & 2.852 & 2.687 & 0.0002 & 0.166 & 1.2905 & 1.5821 & 0.4891 & 0.5696 \\
\hline 4 & Textile & 2.689 & 1.906 & 0.0021 & 0.781 & 1.2166 & 1.1223 & 5.3640 & 2.6871 \\
\hline 5 & $\begin{array}{l}\text { Textile clothing, } \\
\text { shoes and hats, } \\
\text { leather and } \\
\text { products thereof }\end{array}$ & 2.499 & 1.851 & 0.0017 & 0.646 & 1.1306 & 1.0902 & 4.4650 & 2.2220 \\
\hline 6 & $\begin{array}{l}\text { Wood processing } \\
\text { products and } \\
\text { furniture }\end{array}$ & 2.838 & 2.634 & 0.0003 & 0.203 & 1.2840 & 1.5513 & 0.7068 & 0.6992 \\
\hline 7 & $\begin{array}{l}\text { Print paper and } \\
\text { sports culture } \\
\text { and education }\end{array}$ & 2.797 & 2.501 & 0.0004 & 0.296 & 1.2655 & 1.4727 & 1.0819 & 1.0179 \\
\hline 8 & \begin{tabular}{|l|} 
Petroleum, \\
coking products \\
and products \\
processing \\
nuclear fuel
\end{tabular} & 2.542 & 2.140 & 0.0003 & 0.402 & 1.1500 & 1.2600 & 0.8323 & 1.3821 \\
\hline 9 & \begin{tabular}{|l|} 
Chemical \\
products
\end{tabular} & 2.324 & 2.066 & 0.0003 & 0.258 & 1.0514 & 1.2164 & 0.6685 & 0.8876 \\
\hline 10 & $\begin{array}{l}\text { Non-metallic } \\
\text { mineral products }\end{array}$ & 2.337 & 2.105 & 0.0002 & 0.232 & 1.0572 & 1.2395 & 0.5523 & 0.7970 \\
\hline 11 & Metal products & 2.416 & 1.902 & 0.0003 & 0.514 & 1.0932 & 1.1201 & 0.8890 & 1.7676 \\
\hline 12 & $\begin{array}{l}\text { Electric } \\
\text { machinery }\end{array}$ & 2.373 & 1.938 & 0.0003 & 0.434 & 1.0735 & 1.1414 & 0.8201 & 1.4939 \\
\hline 13 & $\begin{array}{l}\text { Transport } \\
\text { equipment }\end{array}$ & 2.652 & 2.150 & 0.0005 & 0.501 & 1.1997 & 1.2662 & 1.1658 & 1.7237 \\
\hline 14 & $\begin{array}{l}\text { Communications } \\
\text { equipment, } \\
\text { computers and } \\
\text { other electronic } \\
\text { devices }\end{array}$ & 2.613 & 1.501 & 0.0019 & 1.111 & 1.1825 & 0.8839 & 4.8819 & 3.8205 \\
\hline 15 & $\begin{array}{l}\text { Repairing } \\
\text { metal products, } \\
\text { machinery and } \\
\text { equipment }\end{array}$ & 2.236 & 1.835 & 0.0004 & 0.400 & 1.0116 & 1.0809 & 0.9167 & 1.3761 \\
\hline 16 & Instrumentation & 2.063 & 1.710 & 0.0004 & 0.352 & 0.9333 & 1.0073 & 0.9805 & 1.2109 \\
\hline 17 & $\begin{array}{l}\text { Machinery, } \\
\text { specialized } \\
\text { equipment }\end{array}$ & 2.036 & 1.556 & 0.0004 & 0.480 & 0.9214 & 0.9162 & 1.1450 & 1.6516 \\
\hline
\end{tabular}




\begin{tabular}{|c|c|c|c|c|c|c|c|c|c|}
\hline \multirow[b]{3}{*}{ No. } & \multirow[b]{3}{*}{ Sectors } & \multicolumn{8}{|c|}{ Vietnam } \\
\hline & & \multirow[b]{2}{*}{$\begin{array}{c}\text { Output } \\
\text { requirements }\end{array}$} & \multicolumn{3}{|c|}{ In which } & \multirow[b]{2}{*}{$\begin{array}{c}\text { Average } \\
\text { of Output } \\
\text { requirements }\end{array}$} & \multicolumn{3}{|c|}{ In Which } \\
\hline & & & $\begin{array}{c}\text { Multiplier } \\
\text { effects }\end{array}$ & $\begin{array}{c}\text { Interregional } \\
\text { feedback } \\
\text { effects }\end{array}$ & $\begin{array}{c}\text { Spillover } \\
\text { Effects }\end{array}$ & & \begin{tabular}{|c} 
Average of \\
Multiplier \\
effects
\end{tabular} & $\begin{array}{c}\text { Average of } \\
\text { Interregional } \\
\text { feedback } \\
\text { effects }\end{array}$ & $\begin{array}{c}\text { Average } \\
\text { of } \\
\text { Spillover } \\
\text { Effects }\end{array}$ \\
\hline 18 & $\begin{array}{l}\text { Other } \\
\text { manufactured } \\
\text { products }\end{array}$ & 2.325 & 1.926 & 0.0006 & 0.398 & 1.0519 & 1.1345 & 1.5044 & 1.3689 \\
\hline 19 & $\begin{array}{l}\text { Producing } \\
\text { and supplying } \\
\text { electricity }\end{array}$ & 1.682 & 1.502 & 0.0002 & 0.180 & 0.7611 & 0.8845 & 0.5345 & 0.6195 \\
\hline 20 & $\begin{array}{l}\text { Producing and } \\
\text { supplying gas }\end{array}$ & 1.558 & 1.393 & 0.0001 & 0.165 & 0.7048 & 0.8201 & 0.3001 & 0.5679 \\
\hline 21 & $\begin{array}{l}\text { Producing and } \\
\text { supplying water }\end{array}$ & 1.978 & 1.722 & 0.0003 & 0.255 & 0.8948 & 1.0142 & 0.7013 & 0.8784 \\
\hline 22 & Waste scrap & 1.978 & 1.722 & 0.0003 & 0.255 & 0.8948 & 1.0142 & 0.7013 & 0.8784 \\
\hline 23 & Build & 2.448 & 2.120 & 0.0003 & 0.328 & 1.1078 & 1.2483 & 0.7175 & 1.1297 \\
\hline 24 & $\begin{array}{l}\text { Wholesale and } \\
\text { retail }\end{array}$ & 1.900 & 1.728 & 0.0002 & 0.172 & 0.8596 & 1.0174 & 0.5308 & 0.5920 \\
\hline 25 & \begin{tabular}{|l|} 
Transportation, \\
warehousing and \\
postal services
\end{tabular} & 2.324 & 1.968 & 0.0003 & 0.355 & 1.0513 & 1.1588 & 0.8257 & 1.2229 \\
\hline 26 & Stay and eat & 2.403 & 2.191 & 0.0003 & 0.213 & 1.0874 & 1.2900 & 0.6403 & 0.7311 \\
\hline 27 & \begin{tabular}{|l|} 
Information \\
transfer, software \\
and information \\
technology \\
services \\
\end{tabular} & 2.453 & 1.859 & 0.0010 & 0.594 & 1.1100 & 1.0946 & 2.5574 & 2.0425 \\
\hline 28 & Finance & 1.831 & 1.744 & 0.0001 & 0.087 & 0.8285 & 1.0269 & 0.2869 & 0.3003 \\
\hline 29 & Real estate & 1.711 & 1.601 & 0.0001 & 0.109 & 0.7741 & 0.9431 & 0.3085 & 0.3762 \\
\hline 30 & \begin{tabular}{|l|} 
Leasing and \\
business \\
services
\end{tabular} & 1.800 & 1.648 & 0.0002 & 0.152 & 0.8146 & 0.9706 & 0.5424 & 0.5228 \\
\hline 31 & $\begin{array}{l}\text { Scientific } \\
\text { research and } \\
\text { technical } \\
\text { services }\end{array}$ & 2.090 & 1.853 & 0.0003 & 0.236 & 0.9454 & 1.0914 & 0.7637 & 0.8119 \\
\hline 32 & Other services & 2.131 & 1.929 & 0.0003 & 0.202 & 0.9641 & 1.1359 & 0.7352 & 0.6936 \\
\hline 33 & Education & 1.663 & 1.543 & 0.0002 & 0.120 & 0.7524 & 0.9087 & 0.4045 & 0.4114 \\
\hline 34 & $\begin{array}{l}\text { Health and social } \\
\text { work }\end{array}$ & 1.995 & 1.764 & 0.0003 & 0.231 & 0.9028 & 1.0387 & 0.6588 & 0.7952 \\
\hline 35 & $\begin{array}{l}\text { Culture, } \\
\text { sports and } \\
\text { entertainment }\end{array}$ & 1.952 & 1.806 & 0.0002 & 0.146 & 0.8834 & 1.0637 & 0.5206 & 0.5020 \\
\hline 36 & \begin{tabular}{|l} 
Public \\
administration, \\
social security \\
and social \\
organization
\end{tabular} & 1.841 & 1.642 & 0.0003 & 0.199 & 0.8331 & 0.9671 & 0.7144 & 0.6839 \\
\hline & Average & 2.210 & 1.887 & 0.0004 & 0.323 & & & & \\
\hline
\end{tabular}

Source: Authors calculated from bilateral input-output table, 2015 
Quang Thai NGUYEN, Bui TRINH, Thang Loi NGO, Manh Dung TRAN /

Appendix 3: Analyzing output requirement induced by a unit increase of final demand of China

\begin{tabular}{|c|c|c|c|c|c|c|c|c|c|}
\hline \multirow[b]{3}{*}{ No. } & \multirow[b]{3}{*}{ Sectors } & \multicolumn{8}{|c|}{ China } \\
\hline & & \multirow[b]{2}{*}{$\begin{array}{c}\text { Output } \\
\text { requirements }\end{array}$} & \multicolumn{3}{|c|}{ In Which } & \multirow[b]{2}{*}{$\begin{array}{c}\text { Average } \\
\text { of Output } \\
\text { requirements }\end{array}$} & \multicolumn{3}{|c|}{ In Which } \\
\hline & & & $\begin{array}{c}\text { Multiplier } \\
\text { effects }\end{array}$ & $\begin{array}{c}\text { Interregional } \\
\text { feedback } \\
\text { effects }\end{array}$ & $\begin{array}{c}\text { Spillover } \\
\text { Effects }\end{array}$ & & $\begin{array}{c}\begin{array}{c}\text { Average } \\
\text { of } \\
\text { Multiplier } \\
\text { effects }\end{array} \\
\end{array}$ & $\begin{array}{c}\text { Average of } \\
\text { Interregional } \\
\text { feedback } \\
\text { effects }\end{array}$ & $\begin{array}{c}\text { Average } \\
\text { of } \\
\text { Spillover } \\
\text { Effects }\end{array}$ \\
\hline 1 & $\begin{array}{l}\text { Agriculture, } \\
\text { forestry, animal } \\
\text { husbandry and } \\
\text { fishery products } \\
\text { and services }\end{array}$ & 1.997 & 1.994 & 0.000 & 0.003 & 0.7516 & 0.7515 & 0.3766 & 0.8987 \\
\hline 2 & Mining & 2.645 & 2.643 & 0.000 & 0.002 & 0.9954 & 0.9960 & 0.5574 & 0.6258 \\
\hline 3 & $\begin{array}{l}\text { Food and } \\
\text { tobacco }\end{array}$ & 2.717 & 2.709 & 0.001 & 0.007 & 1.0222 & 1.0210 & 0.7873 & 2.0363 \\
\hline 4 & \begin{tabular}{|l|} 
Textile \\
\end{tabular} & 3.149 & 3.137 & 0.002 & 0.009 & 1.1848 & 1.1822 & 2.9951 & 2.8642 \\
\hline 5 & $\begin{array}{l}\text { Textile clothing, } \\
\text { shoes and hats, } \\
\text { leather and } \\
\text { products thereof } \\
\end{array}$ & 3.044 & 3.029 & 0.004 & 0.012 & 1.1456 & 1.1416 & 4.4335 & 3.5589 \\
\hline 6 & $\begin{array}{l}\text { Wood processing } \\
\text { products and } \\
\text { furniture }\end{array}$ & 3.111 & 3.096 & 0.002 & 0.013 & 1.1706 & 1.1668 & 1.9135 & 4.1365 \\
\hline 7 & $\begin{array}{l}\text { Print paper and } \\
\text { sports culture } \\
\text { and education }\end{array}$ & 3.163 & 3.159 & 0.001 & 0.004 & 1.1903 & 1.1903 & 1.0445 & 1.2385 \\
\hline 8 & $\begin{array}{l}\text { Petroleum, } \\
\text { coking products } \\
\text { and products } \\
\text { processing } \\
\text { nuclear fuel }\end{array}$ & 2.786 & 2.783 & 0.000 & 0.002 & 1.0483 & 1.0489 & 0.5553 & 0.6696 \\
\hline 9 & $\begin{array}{l}\text { Chemical } \\
\text { products }\end{array}$ & 3.214 & 3.210 & 0.001 & 0.003 & 1.2092 & 1.2097 & 0.6981 & 0.9415 \\
\hline 10 & $\begin{array}{l}\text { Non-metallic } \\
\text { mineral products }\end{array}$ & 3.134 & 3.131 & 0.001 & 0.002 & 1.1791 & 1.1798 & 0.6801 & 0.7550 \\
\hline 11 & Metal products & 3.302 & 3.299 & 0.000 & 0.002 & 1.2424 & 1.2434 & 0.5420 & 0.6119 \\
\hline 12 & \begin{tabular}{|l|} 
Electric \\
machinery \\
\end{tabular} & 3.261 & 3.258 & 0.001 & 0.002 & 1.2270 & 1.2277 & 0.9786 & 0.7208 \\
\hline 13 & $\begin{array}{l}\text { Transport } \\
\text { equipment }\end{array}$ & 3.175 & 3.172 & 0.001 & 0.002 & 1.1948 & 1.1954 & 0.9106 & 0.7694 \\
\hline 14 & $\begin{array}{l}\text { Communications } \\
\text { equipment, } \\
\text { computers and } \\
\text { other electronic } \\
\text { devices }\end{array}$ & 2.706 & 2.698 & 0.003 & 0.005 & 1.0181 & 1.0167 & 3.7997 & 1.5169 \\
\hline 15 & \begin{tabular}{|l|} 
Repairing \\
metal products, \\
machinery and \\
equipment \\
\end{tabular} & 2.828 & 2.826 & 0.001 & 0.002 & 1.0642 & 1.0649 & 0.7816 & 0.5908 \\
\hline 16 & \begin{tabular}{|l|} 
Instrumentation \\
\end{tabular} & 2.735 & 2.731 & 0.001 & 0.003 & 1.0293 & 1.0292 & 1.8232 & 0.9024 \\
\hline 17 & $\begin{array}{l}\text { Machinery, } \\
\text { specialized } \\
\text { equipment }\end{array}$ & 3.136 & 3.133 & 0.001 & 0.002 & 1.1800 & 1.1807 & 0.9680 & 0.7037 \\
\hline
\end{tabular}




\begin{tabular}{|c|c|c|c|c|c|c|c|c|c|}
\hline \multirow[b]{3}{*}{ No. } & \multirow[b]{3}{*}{ Sectors } & \multicolumn{8}{|c|}{ China } \\
\hline & & \multirow[b]{2}{*}{$\begin{array}{c}\text { Output } \\
\text { requirements }\end{array}$} & \multicolumn{3}{|c|}{ In Which } & \multirow[b]{2}{*}{$\begin{array}{c}\text { Average } \\
\text { of Output } \\
\text { requirements }\end{array}$} & \multicolumn{3}{|c|}{ In Which } \\
\hline & & & $\begin{array}{c}\text { Multiplier } \\
\text { effects }\end{array}$ & \begin{tabular}{|c|} 
Interregional \\
feedback \\
effects
\end{tabular} & $\begin{array}{c}\text { Spillover } \\
\text { Effects }\end{array}$ & & $\begin{array}{c}\text { Average } \\
\text { of } \\
\text { Multiplier } \\
\text { effects }\end{array}$ & $\begin{array}{c}\text { Average of } \\
\begin{array}{c}\text { Interregional } \\
\text { feedback } \\
\text { effects }\end{array} \\
\end{array}$ & $\begin{array}{l}\text { Average } \\
\text { of } \\
\text { Spillover } \\
\text { Effects }\end{array}$ \\
\hline 18 & $\begin{array}{l}\text { Other } \\
\text { manufactured } \\
\text { products }\end{array}$ & 3.005 & 2.999 & 0.001 & 0.005 & 1.1306 & 1.1301 & 1.3371 & 1.4953 \\
\hline 19 & $\begin{array}{l}\text { Producing } \\
\text { and supplying } \\
\text { electricity }\end{array}$ & 3.040 & 3.038 & 0.000 & 0.002 & 1.1440 & 1.1450 & 0.4628 & 0.4650 \\
\hline 20 & $\begin{array}{l}\text { Producing and } \\
\text { supplying gas }\end{array}$ & 2.850 & 2.847 & 0.000 & 0.002 & 1.0723 & 1.0729 & 0.5564 & 0.6379 \\
\hline 21 & $\begin{array}{l}\text { Producing and } \\
\text { supplying water }\end{array}$ & 2.612 & 2.610 & 0.000 & 0.002 & 0.9827 & 0.9834 & 0.4845 & 0.4963 \\
\hline 22 & Waste scrap & 3.155 & 3.152 & 0.001 & 0.002 & 1.1873 & 1.1880 & 0.7320 & 0.7539 \\
\hline 23 & Build & 3.147 & 3.144 & 0.001 & 0.003 & 1.1841 & 1.1846 & 0.6978 & 0.8614 \\
\hline 24 & $\begin{array}{l}\text { Wholesale and } \\
\text { retail }\end{array}$ & 1.827 & 1.826 & 0.000 & 0.001 & 0.6875 & 0.6881 & 0.2803 & 0.2414 \\
\hline 25 & $\begin{array}{l}\text { Transportation, } \\
\text { warehousing and } \\
\text { postal services }\end{array}$ & 2.491 & 2.489 & 0.000 & 0.002 & 0.9374 & 0.9381 & 0.4307 & 0.4695 \\
\hline 26 & Stay and eat & 2.405 & 2.400 & 0.001 & 0.005 & 0.9049 & 0.9043 & 0.6272 & 1.4639 \\
\hline 27 & $\begin{array}{l}\text { Information } \\
\text { transfer, software } \\
\text { and information } \\
\text { technology } \\
\text { services }\end{array}$ & 2.127 & 2.125 & 0.001 & 0.002 & 0.8005 & 0.8007 & 1.0703 & 0.5493 \\
\hline 28 & Finance & 1.742 & 1.741 & 0.000 & 0.001 & 0.6554 & 0.6560 & 0.2801 & 0.2704 \\
\hline 29 & Real estate & 1.605 & 1.604 & 0.000 & 0.001 & 0.6039 & 0.6045 & 0.1929 & 0.1885 \\
\hline 30 & $\begin{array}{l}\text { Leasing and } \\
\text { business } \\
\text { services }\end{array}$ & 2.742 & 2.738 & 0.001 & 0.003 & 1.0316 & 1.0318 & 1.0519 & 0.8657 \\
\hline 31 & $\begin{array}{l}\text { Scientific } \\
\text { research and } \\
\text { technical } \\
\text { services }\end{array}$ & 2.518 & 2.515 & 0.001 & 0.002 & 0.9473 & 0.9477 & 0.9755 & 0.6304 \\
\hline 32 & Other services & 2.167 & 2.164 & 0.001 & 0.002 & 0.8152 & 0.8155 & 0.6526 & 0.6044 \\
\hline 33 & Education & 1.497 & 1.496 & 0.000 & 0.001 & 0.5631 & 0.5637 & 0.1644 & 0.2180 \\
\hline 34 & $\begin{array}{l}\text { Health and social } \\
\text { work }\end{array}$ & 2.541 & 2.539 & 0.000 & 0.002 & 0.9563 & 0.9568 & 0.5673 & 0.6385 \\
\hline 35 & $\begin{array}{l}\text { Culture, } \\
\text { sports and } \\
\text { entertainment }\end{array}$ & 2.179 & 2.175 & 0.001 & 0.003 & 0.8200 & 0.8197 & 0.9113 & 0.9734 \\
\hline 36 & $\begin{array}{l}\text { Public } \\
\text { administration, } \\
\text { social security } \\
\text { and social } \\
\text { organization }\end{array}$ & 1.922 & 1.919 & 0.001 & 0.002 & 0.7231 & 0.7232 & 0.6799 & 0.6358 \\
\hline & Total & 2.658 & 2.654 & 0.001 & 0.003 & & & & \\
\hline
\end{tabular}

Source: Authors calculated from bilateral input - output table, 2015 
Appendix 4: Value added creation

\begin{tabular}{|c|c|c|c|c|c|c|c|}
\hline \multirow[b]{2}{*}{ No. } & \multirow[b]{2}{*}{ Sectors } & \multicolumn{3}{|c|}{ Vietnam } & \multicolumn{3}{|c|}{ China } \\
\hline & & $\begin{array}{c}\text { The added } \\
\text { value is } \\
\text { generated } \\
\text { by the final } \\
\text { demand }\left(V_{v} \text {. }\right. \\
\left.X_{v v}\right)\end{array}$ & $\begin{array}{l}\text { Added } \\
\text { value } \\
\text { created } \\
\text { by other } \\
\text { country's } \\
\text { production } \\
\left(\mathrm{V}_{\mathrm{v}} . \mathrm{X}_{\mathrm{vc}}\right)\end{array}$ & $\begin{array}{c}\text { The } \\
\text { total } \\
\text { value } \\
\text { added } \\
\left(\mathrm{V}_{\mathrm{v}}\right)\end{array}$ & $\begin{array}{l}\text { The added } \\
\text { value is } \\
\text { generated } \\
\text { by the } \\
\text { final } \\
\text { demand } \\
\left(V_{c} \cdot X_{c c}\right)\end{array}$ & $\begin{array}{l}\text { Added } \\
\text { value } \\
\text { created } \\
\text { by other } \\
\text { country's } \\
\text { production } \\
\left(V_{c} . X_{\mathrm{cc}}\right)\end{array}$ & $\begin{array}{l}\text { The tota } \\
\text { value } \\
\text { added } \\
\left(V_{c}\right)\end{array}$ \\
\hline 1 & $\begin{array}{l}\text { Agriculture, forestry, animal } \\
\text { husbandry and products and } \\
\text { fisheries service }\end{array}$ & 0.648 & 0.001 & 0.648 & 0.937 & 0.049 & 0.987 \\
\hline 2 & Extractive & 0.582 & 0.001 & 0.583 & 0.849 & 0.071 & 0.919 \\
\hline 3 & Food and tobacco & 0.587 & 0.002 & 0.589 & 0.905 & 0.046 & 0.951 \\
\hline 4 & Textile & 0.425 & 0.002 & 0.427 & 0.876 & 0.216 & 1.092 \\
\hline 5 & $\begin{array}{l}\text { Textile clothing, shoes and hats, } \\
\text { leather and products thereof }\end{array}$ & 0.522 & 0.003 & 0.525 & 0.882 & 0.179 & 1.060 \\
\hline 6 & $\begin{array}{l}\text { Wood processing products and } \\
\text { furniture }\end{array}$ & 0.604 & 0.003 & 0.607 & 0.866 & 0.055 & 0.921 \\
\hline 7 & Print paper and paper products & 0.571 & 0.001 & 0.572 & 0.845 & 0.078 & 0.923 \\
\hline 8 & $\begin{array}{l}\text { Petroleum, coking products and } \\
\text { products processing nuclear fuel }\end{array}$ & 0.432 & 0.001 & 0.432 & 0.778 & 0.110 & 0.888 \\
\hline 9 & Chemical products & 0.498 & 0.001 & 0.499 & 0.829 & 0.067 & 0.896 \\
\hline 10 & Non-metallic mineral products & 0.631 & 0.001 & 0.632 & 0.830 & 0.061 & 0.891 \\
\hline 11 & Metal products & 0.424 & 0.001 & 0.424 & 0.789 & 0.125 & 0.913 \\
\hline 12 & Electric machinery & 0.425 & 0.001 & 0.426 & 0.791 & 0.106 & 0.898 \\
\hline 13 & Transport equipment & 0.489 & 0.001 & 0.489 & 0.811 & 0.126 & 0.937 \\
\hline 14 & $\begin{array}{l}\text { Communications equipment, } \\
\text { computers and other electronic } \\
\text { devices }\end{array}$ & 0.353 & 0.001 & 0.355 & 0.654 & 0.270 & 0.924 \\
\hline 15 & $\begin{array}{l}\text { Repairing metal products, } \\
\text { machinery and equipment }\end{array}$ & 0.511 & 0.000 & 0.512 & 0.832 & 0.098 & 0.931 \\
\hline 16 & Instrumentation & 0.489 & 0.001 & 0.490 & 0.736 & 0.088 & 0.824 \\
\hline 17 & Machinery, specialized equipment & 0.281 & 0.001 & 0.282 & 0.797 & 0.118 & 0.915 \\
\hline 18 & Other manufactured products & 0.532 & 0.001 & 0.534 & 0.851 & 0.104 & 0.955 \\
\hline 19 & Producing and supplying electricity & 0.781 & 0.000 & 0.782 & 0.841 & 0.045 & 0.887 \\
\hline 20 & Producing and supplying gas & 0.813 & 0.001 & 0.813 & 0.802 & 0.040 & 0.842 \\
\hline 21 & Producing and supplying water & 0.671 & 0.000 & 0.671 & 0.904 & 0.068 & 0.972 \\
\hline 22 & Waste scrap & 0.671 & 0.001 & 0.672 & 0.814 & 0.068 & 0.882 \\
\hline 23 & Construction & 0.559 & 0.001 & 0.560 & 0.848 & 0.083 & 0.931 \\
\hline 24 & Wholesale and retail & 0.773 & 0.000 & 0.773 & 0.950 & 0.045 & 0.994 \\
\hline 25 & $\begin{array}{l}\text { Transportation, warehousing and } \\
\text { postal services }\end{array}$ & 0.560 & 0.000 & 0.561 & 0.885 & 0.097 & 0.982 \\
\hline 26 & Accommodation and dining & 0.647 & 0.001 & 0.648 & 0.927 & 0.058 & 0.985 \\
\hline
\end{tabular}




\begin{tabular}{|c|c|c|c|c|c|c|c|}
\hline \multirow[b]{2}{*}{ No. } & \multirow[b]{2}{*}{ Sectors } & \multicolumn{3}{|c|}{ Vietnam } & \multicolumn{3}{|c|}{ China } \\
\hline & & $\begin{array}{l}\text { The added } \\
\text { value is } \\
\text { generated } \\
\text { by the final } \\
\text { demand }\left(V_{v} \text {. }\right. \\
\left.X_{v v}\right)\end{array}$ & $\begin{array}{l}\text { Added } \\
\text { value } \\
\text { created } \\
\text { by other } \\
\text { country's } \\
\text { production } \\
\left(\mathbf{V}_{\mathrm{v}} . \mathrm{X}_{\mathrm{vc}}\right)\end{array}$ & $\begin{array}{c}\text { The } \\
\text { total } \\
\text { value } \\
\text { added } \\
\left(\mathrm{V}_{\mathrm{v}}\right)\end{array}$ & $\begin{array}{l}\text { The added } \\
\text { value is } \\
\text { generated } \\
\text { by the } \\
\text { final } \\
\text { demand } \\
\left(\mathrm{V}_{\mathrm{c}} \cdot \mathrm{X}_{\mathrm{cc}}\right)\end{array}$ & $\begin{array}{l}\text { Added } \\
\text { value } \\
\text { created } \\
\text { by other } \\
\text { country's } \\
\text { production } \\
\left(\mathrm{V}_{\mathrm{c}} . \mathrm{X}_{\mathrm{cv}}\right)\end{array}$ & $\begin{array}{l}\text { The total } \\
\text { value } \\
\text { added } \\
\left(\mathbf{V}_{\mathrm{c}}\right)\end{array}$ \\
\hline 27 & $\begin{array}{l}\text { Information transfer, software and } \\
\text { information technology services }\end{array}$ & 0.604 & 0.000 & 0.604 & 0.878 & 0.146 & 1.023 \\
\hline 28 & Finance & 0.806 & 0.000 & 0.806 & 0.957 & 0.023 & 0.979 \\
\hline 29 & Real estate & 0.853 & 0.000 & 0.853 & 0.970 & 0.028 & 0.998 \\
\hline 30 & Leasing and business services & 0.819 & 0.001 & 0.819 & 0.859 & 0.039 & 0.898 \\
\hline 31 & $\begin{array}{l}\text { Scientific research and technical } \\
\text { services }\end{array}$ & 0.713 & 0.001 & 0.713 & 0.848 & 0.059 & 0.908 \\
\hline 32 & Other services & 0.743 & 0.001 & 0.743 & 0.908 & 0.052 & 0.961 \\
\hline 33 & Education & 0.845 & 0.000 & 0.845 & 0.966 & 0.031 & 0.997 \\
\hline 34 & Health and social work & 0.563 & 0.001 & 0.563 & 0.883 & 0.060 & 0.943 \\
\hline 35 & Culture, sports and entertainment & 0.805 & 0.001 & 0.806 & 0.922 & 0.038 & 0.960 \\
\hline 36 & $\begin{array}{l}\text { Public administration, social } \\
\text { security and social organization }\end{array}$ & 0.776 & 0.001 & 0.776 & 0.937 & 0.051 & 0.988 \\
\hline & Average & 0.611 & 0.001 & 0.612 & 0.860 & 0.083 & 0.943 \\
\hline
\end{tabular}

Source: Authors' calculations via intercountry input - output table between Vietnam and China, 2015 